\title{
УANALOGISEN MIKSAUSKONSOLIN ELINKAARI KOLMEN LAITEYKSILÖN KÄYTTÖVAIHEIDEN KAUTTA TARKASTELTUNA
}

Kai Lassfolk

Miksauskonsoli (engl. Mixing Console, saks. Mischpult) on nimitys musiikkistudioiden keskeiselle äänityslaitteelle. Laite on keskeinen sananmukaisesti, koska se sijaitsee keskellä studion äänitarkkaamoa, eikä laitetta voi olla kokonsa ja sijaintinsa vuoksi huomaamatta. Miksauskonsolin tärkein tehtävä on miksata eli sekoittaa eri äänilähteiden signaalit summasignaaliksi. Konsoli-termi viittaa kaappimaiseen, usein kaltevaan ulkomuotoon ja fyysiseen kokoon. Muita yleisiä laitetyypin nimityksiä ovat miksauspöytä (Mixing Desk, Mixing Board) viitaten pöytämäiseen ulkomuotoon tai pelkkä mikseri (Mixer) viitaten toiminnallisuuteen. Tämä artikkeli käsittelee analogiaelektroniikkaan perustuvien miksauskonsolien kehitystä kolmen esimerkkilaitteen kautta. Erityisesti tekstissä keskitytään käyttäjien tapoihin soveltaa mikseriteknologiaa sekä siihen, miten käyttötavat ovat yhdessä elektroniikan kehityksen kanssa vaikuttaneet mikseriteknologian kehitykseen.

\section{JOHDANTO}

Tarkastelen tässä artikkelissa analogiaelektroniikkaan perustuvien miksauskonsolien kehitystä kolmen esimerkkilaitteen, EMIyhtiön REDD.51:n, Decca-yhtiön Wienin Sofiensaalin studion WSW-mikserin ja Sound City -studion Neve 8028 -mikserin, kautta. Artikkelin päätutkimuskysymys on, miten miksauskonsolin käyttäjät ovat esiintyneet teknologian käytön ja kehityksen toimijoina. Tarkentavina kysymyksinä ovat, miten käyttäjät ja heidän roolinsa heijastuvat mikserin teknologiassa ja käyttöliittymässä sekä millaisia vuorovaikutussuhteita teknologian hyödyntämiseen liittyy.

Artikkelin teoreettisena viitekehyksenä on teknologian sosiaalisten konstruktioiden tutkimus (Social Construction of Technology, SCOT $^{1}$ ). Vaikka SCOT ei tarjoa yhtenäistä ja systemaattista taustateoriaa, sen teknologian ja käyttäjien vuorovaikutuksen synnyttämän kehityksen tutkimusparadigma ja tämän pohjalta tehdyt tapaustutkimukset antavat keinoja ja käsitteistöä analysoida yksittäisen laitetyypin kehitystä laajempana ja monitahoisempana ilmiönä kuin pelkästään suunnittelijoidensa tai keksijöidensä aikaansaannoksena. Tätä kautta miksauskonsolien kehitys vertautuu erityisesti teknologioihin, jotka ovat käyneet tietyn kehityskaaren, muuttuneet tämän aikana käyttäjiensä vaikutuksesta ja vaikuttaneet uusien teknologioiden kehittymiseen.

Analyysin pohjaksi artikkeli esittelee uuden nelivaiheisen teknologian elinkaarimallin, joka on yksinkertaisempi kuin esimerkiksi Wiebe Bijkerin käyttämät moniportaiset kehitysmallit. Elinkaarimalli sallii toisaalta myös epälineaarisen ja limittyvän kehitysvaiheiden tarkastelun. Aiemmassa studioteknologian historian tutkimuksessa teknologioita on käsitelty yleensä joko jonkin yksittäisen musiikkigenren piirissä tai huomioimatta laitteiden käyttökontekstia. Tämä artikkeli lähes- 
tyy mikseriteknologiaa sekä klassisen että populaarimusiikin äänituotantojen käyttöyhteyksien kautta. Tuotteen elinkaaren käsitettä on käytetty tutkimuksessa jo pitkään ja sen ympärille on rakentunut oma etupäässä massatuotteiden tilastolliseen tutkimukseen perustuva PLC-tutkimusparadigmansa. ${ }^{2}$ Tässä tutkimuksessa elinkaari toimii kehystävänä käsitteenä alla kuvatulle nelivaiheiselle jaottelulle, jossa tarkastelu perustuu yksittäisiin tapausesimerkkeihin sekä näistä löydettäviin, teknologian kehitystä kuvaaviin ja yhdistäviin piirteisiin.

Syy mainittujen laitteiden valintaan on se, että niistä kukin edustaa lajityyppinsä eri käyttöympäristöjä ja tiettyä teknologista kehitysvaihetta; toisaalta laiteyksilöt ja niiden edustama teknologia on nostettu esiin useissa yhteyksissä. Tätä kautta ne ovat saavuttaneet erityisaseman äänittäjien tai äänitysteknologiasta kiinnostuneen yleisön keskuudessa.

Artikkelin tutkimusaineisto on poimittu mainittujen laitteiden erityissyyttä korostavien kirjallisten, video- ja verkkomateriaalien joukosta. Tutkimuksen osakysymyksenä onkin, millaista kuvaa aineiston dokumentit luovat käsittelemistään teknologioista. Keskeisenä aineistona ovat Ryanin ja Kehew'n kirja Recording the Beatles ${ }^{3}$, BBC:n dokumenttifilmi The Golden Ring Richard Wagnerin Jumalten tubo-oopperan äänityksestä Wienin Sofiensaalissa ${ }^{4}$ sekä Dave Grohlin ohjaama videodokumentti Sound City - samannimisestä äänitysstudiosta ${ }^{5}$. Näitä täydennän kirjallisista lähteistä, valokuvamateriaalista ja verkkolähteistä kootulla vertailuaineistolla ja aiemmilla studioteknologian historian tutkimuksilla. Kaikki tutkimusaineisto on aiemmin julkaistua.

Mainitut kolme keskeistä aineiston lähdettä ovat keskenään hyvin eri tyyppisiä. Ryanin ja Kehew'n kirja on saavuttanut arvostetun aseman Beatles-tutkimuksen joukossa. Vaikka se ei olekaan formaali tieteellinen julkaisu, se perustuu pit- kään ja systemaattiseen arkisto- ja haastattelututkimukseen sekä ansiokkaisiin ääniteanalyyseihin. Sitä voikin pitää varsin luotettavana kuvauksena EMI:n Lontoon studion 1960-luvun teknologiasta ja tämän soveltamisesta. Tämän artikkelin kannalta kirja sisältää erityisesti perinpohjaisen kuvauksen EMI:n REDD.51-mikserin teknologiasta sekä kuvauksia sen luovista käyttötavoista The Beatles -yhtyeen äänityksissä.

The Golden Ring -filmi on aikalaisdokumentti ja kuvaa ainakin osin autenttisia tilanteita oopperan äänitys- ja editointisessioista. Tämän tekstin kannalta kiinnostavinta on dokumentin tapa tuoda esiin miksauskonsolin käyttöä ja keskeistä asemaa äänituotannossa äänitystilanteiden filmatisoinnin ja haastattelujen kautta.

Dave Grohlin dokumentti kuvaa losangelesilaisen Sound City -studion vaiheita valokuvien, äänitteiden ja dokumenttia varten kuvattujen haastattelujen avulla. Näistä ohjaaja on rakentanut kronologisesti, nopeiden leikkausten avulla etenevän kertomuksen. Grohlin dokumentissa on kuitenkin huomattava, että haastateltavia on ehkä ohjattu antamaan tai heiltä on leikattu mukaan ohjaajan tavoittelemaa kertomusta vahvistavia lausuntoja. Kiinnostavaksi ja relevantiksi aineistoksi dokumentin tekee sen tapa korostaa studion miksauskonsolin erityisyyttä lukuisien haastattelulausuntojen ja käytännön äänitystyön videokuvauksen kautta. Dokumentti kuvaa myös kokeneiden muusikoiden näkemyksiä studioteknologian ja -työskentelyn muutoksista, mikä puolestaan linkittyy aihetta käsittelevään musiikkiteknologian tutkimukseen. ${ }^{6}$ Olen aiemmin käsitellyt Grohlin dokumenttia lähemmin Musiikin suunta -lehden artikkelissani. ${ }^{7}$

Artikkelin aineistossa on myös musiikkiteknologiaan keskittyvän Gearslutzfoorumin verkkokeskustelu, ${ }^{8}$ joka on käyty nimimerkeillä. Syinä tämän aineiston käyttöön ovat yhtäältä sen sisältämät kuvaukset ja ainutlaatuiset valokuvat Sofiensaalin 
mikserin teknologiasta ja restaurointiprosessista sekä toisaalta keskustelusta heijastuva kirjoittajien suhtautuminen konsoliin. Tämän kaltaiset verkkokeskustelut ovat osa internetin piirissä toimivan musiikkiteknologiaharrastajien muodostaman väljän sosiaalisen ryhmän kollektiivista tiedonhankintaa ja mielipiteenmuodostusta.

Käsittelen tapausesimerkeiksi valittujen konsolien kehitystä laitteen elinkaaren (life cycle) kautta, jonka jaan neljään käyttövaiheeseen: 1) käyttö aiotussa ja suunnitellussa tehtävässä, 2) vanhentuneen laitteen käyttö kierrätetyssä, suunnittelemattomassa tehtävässä, 3) restaurointi ja uusiokäyttö tai museointi sekä 4) laitteen teknologian kopiointi ja digitaalimallinnus. Jako vaiheisiin on karkea ja sen soveltaminen käytäntöön riippuu tulkinnasta, joka puolestaan perustuu rajalliseen lähdetietoon. Joissain tapauksissa 2. ja 3. vaiheen selkeä erottaminen voi olla vaikeaa, koska kummassakin on kyse laitteen käytöstä muuhun kuin suunniteltuun tarkoitukseensa. Perusteena näiden luokittelemiselle erillisiksi vaiheiksi on, että näiden välissä elinkaaressa tapahtuu merkittävä murros, esimerkiksi pitkä tauko käytössä tai laitteen purkaminen osiin ja uudelleen kokoaminen. Toisaalta vaiheet eivät välttämättä seuraa toisiaan lineaarisesti yllämainitussa järjestyksessä. Vaiheiden keskinäinen järjestys voi vaihdella ja samaan käyttötilanteeseen voi sisältyä piirteitä useammasta kuin yhdestä vaiheesta. Käyttäjät vaikuttavat yksittäisen laitteen elinkaareen esimerkiksi niin, että laitetta ei koskaan käytetä suunniteltuun käyttötarkoitukseensa tai siitä muodostuu erityisen tehokas työväline aivan muussa kuin suunnitellussa käytössä.

SCOT:in näkökulmasta miksauskonsolien teknologiaa tarkastellaan artikkelissa käyttäjiensä toimintaa mahdollistavana ja toisaalta rajoittavana teknologisena kebyksenä (technological frame), jonka artefakteja ovat elinkaaren kolmessa ensimmäisessä vaiheessa alkuperäislaitteet ja neljännessä laitekopi- ot, digitaalimallinnukset sekä digitaalisten äänityöasemien toiminnot ja ohjainlaitteet. Miksauskonsolin tapauksessa myös yksittäinen artefakti voi olla teknologinen kehys, koska esimerkiksi EMI:n Lontoon studion kaikissa äänitarkkaamoissa oli lähes läpi 1960-luvun jokin REDD-sarjan konsoli, joka toimi näin käytännössä koko teknologian edustajana. Teknologisen kehyksen kautta artikkelissa tarkastellaan mikseriteknologian ja sen piirissä toimivien sosiaalisten rybmien vuorovaikutusta, ${ }^{9}$ joka laajenee ammattilaisten muodostamasta pienestä, jopa henkilöittäin nimettävissä olevasta joukosta anonyymiksi tai nimimerkeillä esiintyväksi ääni- ja musiikkiteknologia-alan ammattilais- ja harrastajakunnaksi.

Laitteen elinkaaren vaiheesta 1 käytetään jatkossa lyhyempää nimitystä suunniteltu käyttö, vaiheesta 2 sunnittelematon käyttö, vaiheesta 3 unsiokäyttö ja vaiheesta 4 kopiointi. Lukujen otsikot on nimetty näiden mukaan. Ennen käyttövaiheiden käsittelyä artikkelissa käydään läpi miksauskonsolien yleistä kehitystä. Loppupuolella on puolestaan temaattisiin lukuihin jaettu yhteenveto-osuus.

\section{KATSAUS MIKSAUSKONSOLIN YLEISEEN KEHITYKSEEN}

Sähköisen äänentallennuksen alkuaikoina 1920- ja 1930-luvulla miksauslaitteisto haki vielä muotoaan. Myös käyttötarpeet vaihtelivat suurista pysyvistä radio- ja levytaltioinneista siirreltäviin ulkolähetys- ja taltiointitehtäviin. Miksauskalusto vaihteli erillisistä laitteista kootuista tilapäisrakennelmista ${ }^{10}$ kiinteisiin konsolimaisiin tai kirjoituspöytää muistuttaviin työpisteisiin ${ }^{11}$ sekä kaappimaisiin, seisaaltaan operoitaviin vahvistinlaitteistoihin. Äänenvoimakkuussäätiminä käytettiin usein kiertopotentiometreja 1960-luvun mittaan yleistyneiden liukusäätimien sijaan. Näitä varhaisia laitteita voikin olla vaikea tunnistaa miksereiksi. Elektroni- 
putki oli vielä 1950-luvulla vallitseva vahvistinkomponentti ja vaati fyysisen kokonsa ja lämmöntuoton vuoksi tilaa, mikä teki laitteistoista kookkaita ja kalliita.

Äänitysstudiossa alettiin käyttää monimikrofonitekniikkaa samaan aikaan stereotallennuksen yleistymisen kanssa. ${ }^{12}$ Mikrofonimäärän kasvaessa miksauksesta tuli olennainen osa äänituotantoprosessia. Myös moniraitanauhurit alkoivat vähitellen yleistyä, jolloin miksaus muuttui osin erilliseksi, äänitystapahtuman jälkeen suoritetuksi jälkituotantovaiheeksi. Äänikanavien lisääntyessä myös miksauskonsoleista tuli kooltaan suuria. Ergonomia puolestaan ohjasi laitteiden muotoilua niin, että mikseri alkoi muistuttaa perinteistä toimistotyöpöytää. Ääniteknikon työstä tuli istumatyötä siksikin, että LP-levyn mahdollistamat pitkät, jopa kokonaisia oopperateoksia sisältävät levyjulkaisut vaativat myös pitkiä äänitysprosesseja.

1950-luvulla mikserien toiminnallisuus alkoi vakiintua: suuren äänitysstudion mikserissä oli tyypillisesti muutama tai kymmenkunta kanavaa sisään tuleville signaalilähteille sekä joukko rybmiä ulos menevälle signaalille, joihin kanavien signaali miksattiin säätämällä näiden äänenvoimakkuussäätimiä. Ryhmissä oli omat voimakkuussäätimensä kokonaistason säätämiseen. Kanavissa oli usein myös äänensävyn säätimiä. Stereoäänittämistä varten suunnitelluissa mikserikanavissa oli yleensä myös panorointisäädin äänen sijoittamiseksi stereokuvaan. Miksereissä oli yleensä myös signaalin voimakkuustason mittarit.

1960-luvun loppupuolella puolijohdeteknologia alkoi yleistyä studiolaitteissa. Transistorit mahdollistivat toisaalta kooltaan pienempien, toisaalta kanavalukumäärältään suurempien mikserien rakentamisen. Miksereihin alettiin integroida aiemmin erillislaitteilla toteutettuja toimintoja, kuten voimakkuustason kompressoreita ja monipuolisempia äänensävyn säätimiä. Puolijoh- deteknologia helpotti myös nauhurien raitalukumäärän kasvattamista, mikä puolestaan lisäsi mikserien ominaisuusvaatimuksia.

1960- ja 1970-luvuilla Englantiin syntyi pop-musiikkiteollisuuden voimakkaan kasvun myötä kymmeniä merkittäviä levyyhtiöiden omistamia ja näistä itsenäisiä, riippumattomia äänitysstudioita. ${ }^{13}$ Näin myös miksauskonsolien kysyntä kasvoi voimakkaasti. Tämä puolestaan synnytti miksereiden suunnitteluun ja valmistukseen erikoistuneita yrityksiä, kuten Trident, Neve ja Solid State Logic. Myös aiemmin omaan laitevalmistukseen nojanneet isot yhtiöt, esimerkiksi EMI, alkoivat hankkia miksereitä näiltä erikoistuneilta valmistajilta. Saman tyyppistä kehitystä tapahtui myös PohjoisAmerikassa. ${ }^{14}$

1980-luvulla puolijohdeteknologian kehittyminen mahdollisti elektroniikan suuremman integroimisen, joka puolestaan mahdollisti yhtäältä mikserien äänikanavien ja ominaisuuksien lisäämisen ilman fyysisen koon kasvattamista ja toisaalta pienten, integroitujen mikserien valmistamisen. Samalla laitteiden toimintavarmuus parani, mikä helpotti toimintojen mahduttamista yhä pienempään tilaan.

Integrointi laski myös valmistuskustannuksia. 1980-luvulla alkoivat yleistyä ns. projekti- ja kotistudiot, mikä loi sekä kysyntää että tarjontaa kohtuuhintaisille studiolaitteille. Ammatti- ja harrastajamuusikot alkoivat enenevässä määrin tehdä äänityksiä omissa studioissaan. Myös digitaalitekniikka alkoi tehdä voimalla tuloaan sekä isoihin ammattistudioihin että kotistudioihin. 1983 esitelty MIDI-liitäntä, mikrotietokoneet, digitaalisesti ohjatut syntetisaattorit ja sämplerit mahdollistivat äänituotannon varsin yksinkertaisella ja halvahkolla kalustolla ilman massiivista moniraitanauhurilaitteistoa ja isoa miksauskonsolia.

Suurin mullistus tapahtui kuitenkin 1990-luvulla ja 2000-luvun alussa, kun mikrotietokoneiden laskentakapasiteetti saavut- 
ti riittävän tason moniraitaisten digitaaliäänitysten tekemiseen. Myös miksaus voitiin suorittaa kokonaan tietokoneella (engl. "in the box") ilman erillistä mikserilaitetta ja prosessi voitiin automatisoida täysin. Vaikka automaatiota käytettiin jo kehittyneissä analogisissa miksereissä, se rajoittui yleensä kanavien voimakkuustasojen säätöön. Tietokonetyöskentelyssä vanhoista miksauskonsoleista jäivät kuitenkin muistuttamaan digitaalisten äänityöasema- eli DAWohjelmien visuaalinen, analogista mikseriä muistuttava käyttöliittymä ja liukusäätimillä varustetut, niin ikään mikseriä muistuttavat DAW-ohjaimet, eli lisälaitteet, joilla tietokoneelle syötetään parametritietoa miksausta varten.

Tietokoneiden myötä miksauksesta poistui analogiaelektroniikan vaikutus äänitteen kokonaissointiin. Samoin poistui tarve suorittaa miksaus musiikkiesitystä muistuttavana ainutkertaisena tapahtumana, johon saattoivat osallistua äänittäjän lisäksi tuottaja ja muusikot. Mikserin merkityksestä Ryan ja Kehew mainitsevat esimerkkinä The Beatlesin Abbey Road-albumin. ${ }^{15}$ Se poikkeaa kirjoittajien mukaan soinniltaan selvästi yhtyeen aiemmista albumeista, vaikka näitä erottaa laitteiston osalta vain yksi merkittävä komponentti: mikseri.

Digitaaliäänittämisen usein "steriiliksi" tai "persoonattomaksi" luonnehdittua sointia onkin monipuolistettu analogiakonsoleiden vahvistinmoduuleita ja analogisia äänenmuokkauslaitteita mallintavien ohjelmistoliitännäisten avulla. Näistä on lyhyessä ajassa tullut yleisiä työvälineitä, joiden käyttäjäkunta on laajempi kuin esikuvalaitteidensa. Myös analogialaitteilla on edelleen käyttäjänsä. Erityisesti mikrofonietuvahvistimet, joista monet ovat kopioita klassikkomikserien kytkennöistä, ovat edelleen äänitysstudioiden peruskalustoa. Erityisesti tiettyjä klassikkolaitteita valmistetaan yhä sekä kaupallisten laitevalmistajien että laiterakentelijoiden toimesta. Studiolaiteraken- telusta onkin 2000-luvulla tullut suosittua. Suuria miksereitäkin valmistetaan ja käytetään yhä, erityisesti live-äänentoistossa. Tosin tässäkin tehtävässä digitaalimikserit ovat jo osin korvanneet analogialaitteet.

Miksauskonsolien piirissä toimivat sosiaaliset ryhmät olivat alussa suppeita. 1960-luvun loppupuolelle asti EMI:n Lontoon studiossa äänityksissä käytetty miksauskonsoli oli äänittäjän (Balance Engineer) työväline. Hänen ohellaan äänitarkkaamossa työskentelivät yleensä ainakin nauhaoperaattori (Tape Op) ja tuottaja. Vuosikymmenen edetessä miksaustapahtumaan osallistuneet muusikot laajensivat mikseriteknologian sosiaalista ryhmää. Äänityshenkilökunnan tiukan rooli- ja tehtäväjaon väljentyessä mikserin käyttäjäkunta laajeni edelleen.

Projekti- ja kotistudioiden myötä musiikin harrastajista tuli oma mikseriteknologian sosiaalinen ryhmänsä, joka ei enää ollut rajattavissa tai yksilöitävissä. Tälle suunniteltiin myös omia, erityisesti projektistudioihin tarkoitettuja miksereitä. Tietokoneiden yleistyessä mikseriteknologian digitaalisille artefakteille oli näin jo valmis sosiaalinen ryhmä, joka omaksui uuden teknologian varsin nopeasti.

\section{EMI REDD.51 KONSOLI}

Englantilainen EMI-yhtiö ratkaisi 1950-luvulla miksauslaitetarpeensa suunnittelemalla miksauskonsolisarjan, jonka eri malleja käytettiin suuryhtiön äänitysstudioissa ympäri maailman. Sarjan ensimmäinen malli, REDD.17 perustui saksalaiseen CLGkonsoliin. ${ }^{16}$ REDD.17 sekä tätä seuranneet REDD.37 ja REDD.51 olivat modulaarisia rakennelmia, jossa oli kymmeniä koteloituja vahvistinkasetteja mikrofoneista, äänitallentimista ja äänenmuokkauslaitteista tulevien signaalien vahvistamiseen sekä äänenvoimakkuussäätimien ja äänensävyn 
Kuva 1. EMI REDD.17 -konsoli symmetrisine käyttöliittymäasetteluineen.

säätöön tarkoitettujen suotimien aiheuttamien signaalihäviöiden kompensointiin. Kasetit olivat näkyvissä konsolin sivuilla, ja ne voitiin vaihtaa nopeasti vikatilanteessa. Mikseri suunniteltiin liikuteltavaksi ja se oli purettavissa osiin kuljetusta varten. Mikserin käyttöliittymä noudatti symmetristä

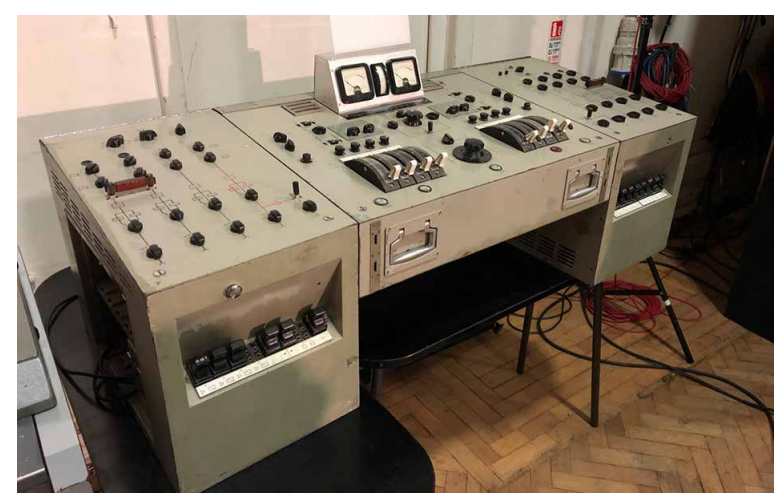
asettelua: kahdeksan sisääntulokanavan säätimistä puolet oli sijoitettu konsolin vasemmalle ja puolet näiden peilikuvana oikealle puolelle, ryhmien säätimet puolestaan keskelle äänittäjän istumapaikan eteen (ks. kuva $1)$.

REDD.17 suunniteltiin nauhureilla tapahtuvaa stereofonista äänituotantoa silmällä pitäen. Laitteen suunnitteluun vaikutti suuresti klassisen musiikin, erityisesti orkesteri- ja oopperamusiikin äänittäminen. Kehittyneemmät 4-raitaäänityksiin suunnitellut mallit, REDD.37 ja REDD.51, olivat keskenään toiminnoiltaan lähes identtisiä. REDD.51:ssä yhtiön pyrkimys omavaraiseen laitetuotantoon näkyi siinä, että edeltävän REDD.37-mallin saksalaisvalmisteiset, Telefunken-yhtiön lisenssiin perustuneet V72-vahvistinkasetit korvattiin EMI:n omilla REDD.47-vahvistimilla. Kuuluisin REDD.51-konsoli oli EMI:n Lontoon studioiden, nykyisin Abbey Road Studios -nimellä tunnetun studiokompleksin Studio 2:n mikseri, joka on tullut tunnetuksi The Beatles -yhtyeen 1960-luvun äänityksistä ja lukuisista yhtyeen levytyssessioista otetuista valokuvista. Klassisen musiikin orkesteriäänityksiin tarkoitettu Studio 1 oli puolestaan varustettu REDD.37-konsolilla koko 1960-luvun. ${ }^{17}$

Studioiden tallenninkaluston selkärangan muodostivat EMI:n omat monofoniset BTR-2- ja stereofoniset BTR-3-nauhurit sekä Telefunkenin ja Studerin valmistamat

neliraitanauhurit. REDD.37:ssä ja 51:ssä signaalireititys ja käyttöliittymä oli suunniteltu nimenomaan neliraitanauhurien ominaisuuksia silmällä pitäen ja miksereissä oli tätä varten neljä ryhmää. Klassisen musiikin äänityksissä voitiin esimerkiksi tallentaa orkesteri stereofonisena kahdelle raidalle ja laulu- tai soitinsolistit monofonisina lopuille kahdelle raidalle. Miksausvaiheessa solistikanavat voitiin sijoittaa stereokuvaan REDD-konsolin panorointisäätimillä orkesterin stereosignaalin sekaan.

\section{SofiensaAlin WSW-KOnSOLI}

Decca-yhtiöllä oli 1950-1990 -luvuilla Wienin Marxergassella sijaitsevassa, kylpylästä tanssiaissaliksi muunnetussa Sofiensaalin rakennuksessa pysyvä äänitysstudio, jota käytettiin ooppera- ja orkesteriäänituotantoihin. Äänitykset tehtiin alkuvaiheessa erillislaitteista kasatulla laitteistolla, joka korvattiin 1964 uudella, erityisesti suuria äänituotantoprojekteja varten suunnitellulla miksauskonsolilla. Deccalla oli tällöin meneillään John Culshaw'n tuottama Richard Wagnerin Nibelungin sormus -oopperatetralogian ensimmäinen kokonaislevytys. Sofiensaalin mikseri valmistui tetralogian päätösosan, Jumalten tuhon äänitykseen ja sitä käytettiin myös Valkyyrian äänityksessä, joka tehtiin oopperoista viimeisenä. 
Mikserin suunnittelivat Culshaw'n mukaan $^{18}$ Deccan äänittäjät Gordon Parry ja James (Jimmy) Brown, jotka myös käyttivät mikseriä Wagnerin Ringin äänityksissä ja muodostivat yhdessä Culshaw'n kanssa Ring-tuotannon äänituotantoryhmän ytimen. Mikserin valmistuksesta vastasi wieniläinen WSW-yhtiö. Mikseri varustettiin WSW:n omilla mikrofonivahvistinmoduuleilla ja Deccan äänensävynsäätömoduuleilla. Elektroniikka koostui sekä elektroniputkista että transistoreista.

Elektroniikkaan liittyviä ratkaisuja näkyvämpi erityispiirre oli kuitenkin mikserin käyttöliittymäasettelu. Culshaw'n mukaan $^{19}$ keskeinen tavoite suunnittelussa oli, että mikseriä pystyi käyttämään samanaikaisesti kaksi äänittäjää. Mikserin valokuvista ${ }^{20}$ näkyy selvästi paitsi kahden äänittäjän työpisteet, myös äänitystyöryhmän tuottajakeskeinen työjärjestys: kahden samanlaisen, symmetrisesti toisiinsa nähden asetellun mikrofonikanavien ja ryhmien säädinrykelmän välissä on tuottajan työpöytä nuottitelineineen, komentomikrofoneineen ja puhelimineen.

\section{Sound Cityn Neve 8028}

Losangelesilainen riippumaton äänitysstudio Sound City tilasi vuonna 1973 Neve-yhtiöltä miksauskonsolin pystyäkseen kilpailemaan isojen artistien levytysprojekteista. ${ }^{21}$ Korkealuokkainen mikseri koettiin studion johdon taholta ratkaisevan tärkeäksi kilpailueduksi ja siihen oltiin valmiita sijoittamaan huomattava rahasumma. Sound Cityn Neve 8028 -mikserin ostohinta oli yli 75000 dollaria (nykyarvoltaan yli 420000 dollaria $^{22}$ ).

Neven miksauskonsolit koottiin asiakkaan tilauksesta, mutta teknologia oli modulaarista ja sarjatuotantona valmistettua. Sound Cityn konsolin asettelu noudatti 1960-luvun mittaan yleistynyttä käytäntöä, jossa äänikanavat (Sound Cityn Nevessä 24 kappaletta) oli sijoitettu järjestyksessä pöydän vasemmalle puolelle. Kussakin kanavassa oli (miksaajasta katsottuna takaa eteen lukien) ryhmävalitsinmoduuli 16 ryhmälle (ts. 8 stereoparille) stereopanorointisäätimineen, mikrofoni-/linjavahvistinmoduuli, Aux- eli apulähtövalitsinmoduuli sekä äänenvoimakkuustason liukusäädin. Kanavaliukusäätimien oikealla puolella olivat 16 ryhmän ja pääsignaaliulostulojen tasonsäätimet. Kanavien oikealla puolella oli joukko kompressorimoduuleja ja näiden edessä monitorointivalitsinpaneelit moniraitanauhurin 24 kanavalle. Konsolin yläosassa oli mittaristo ja oikeassa laidassa ristikytkentäpaneeli. Kaiken kaikkiaan Neve-konsoli muistutti toiminnoiltaan ja käyttöliittymäasettelultaan tyypillistä nykyaikaista analogista mikseriä ja edusti näiden osalta teknologian vakiintumisvaihetta.

1960- ja 1970-luvun vaihteen Nevemikserit perustuivat erillistransistoritekniikkaan. Transistorit voitiin putkia pienempinä ja vähemmän lämpöä tuottavina sijoittaa suoraan mikserin pöytätasoon asennettuihin moduuleihin. Vahvistinmoduuleihin voitiin myös integroida muun muassa äänensävynsäätimiä. Konsoliin voitiin myös asentaa aiemmin erillislaitteina hankittuja äänenmuokkaustoimintoja, kuten Sound Cityn 8028:n kompressorimoduulit. Suuren kanava- ja moduulimääränsä vuoksi Sound Cityn konsoli oli vaakatasossa kookkaampi kuin REDD.51, mutta erillisen tuottajan työpisteen puuttumisen vuoksi pienempi kuin Sofiensaalin mikseri. Myös lämmöntuotto oli kokonaisuutena suurta mikserissä käytettyjen A-luokan vahvistinkytkentöjen vuoksi, jotka kuluttivat paljon ja jatkuvasti virtaa mikserin ollessa päällä. Silti juuri elektroniikkakytkentöjensä ja niiden tuottaman ominaissoinnin vuoksi Neven mikserimoduuleista tuli projektistudioiden ja digitaaliteknologian aikakaudella keräilyn ja kopioinnin kohteita. 


\section{MIKSERIEN SUUNNITELTU KÄYTTÖ}

Abbey Roadin Studio 2:n REDD.51-konsolin suunniteltu käyttövaihe ajoittui vuoden 1964 alusta 1968 lopulle, jolloin studiossa otettiin käyttöön ensimmäinen 8-raitanauhuri kesken The Beatles -albumin äänitysten. EMI:n pop-musiikkijulkaisut olivat käyttövaiheen aikana pääosin monofonisia. Siksi The Beatlesinkin tuotannoissa mikserin kanavia käytettiin pelkästään monofonisina. Stereotoimintoja, esimerkiksi panorointia, käytettiin vain etupäässä Yhdysvaltojen markkinoille suunnatuissa stereomiksauksissa, jotka tehtiin päätuotteena toimineiden ja huolellisesti tehtyjen monomiksausten jälkeen varsin suoraviivaisesti ja nopeasti. ${ }^{23}$

Ryan ja Kehew käyvät yksityiskohtaisesti läpi mikserin käyttöä The Beatlesin musiikkikappaleiden äänitysprosessien analyysien kautta. Heidän mukaansa käytännöt muuttuivat asteittain eräänlaisena kompromissina EMI-yhtiön yhtäältä jäykkien tuotantosääntöjen ja henkilöstön tiukan roolituksen sekä toisaalta äänitysteknikoita innovaatioihin kannustavan palkitsemispolitiikan välillä. Yhtiön tuottavimpana artistina The Beatles sai myös erivapauksia kiertää laitteiden käyttöä rajoittavia sääntöjä.

1. käyttövaiheen edetessä Beatlesin sovitukset monimutkaistuivat ja mikserin kanavalukumäärä ei enää riittänyt rumpujen monimikrofoniäänityksiin. Tämä ratkaistiin kytkemällä rummuille varattuun kanavaan pieni apumikseri. Pääosin REDD.51:n ominaisuudet silti riittivät neliraitaäänityksiin jopa silloin, kun raitalukumäärää kasvatettiin kopioimalla ja välimiksaamalla äänityksiä neliraitanauhurilta toiselle. Koska monofoninen äänittäminen oli talon käytäntö popmusiikkituotannossa REDD.51-konsolin suunnitteluvaiheessa, voidaan The Beatles -albumia edeltävää äänituotantoa pitää REDD-konsolin suunniteltuna käyttövaiheena. Apumikserin käyttö osoitti kuitenkin jo pyrkimystä ulos teknologian rajoituksista, mikä myöhemmin johti 2. käyttövaiheeseen.
Sofiensaalin mikserin käyttö suunnitellussa tarkoituksessaan kesti vuodesta 1964 vuoteen 1975. ${ }^{24}$ Mikserin suunniteltu käyttötapa tulee hyvin esiin The Golden Ring -filmissä. Tuottajan paikalla istuva Culshaw jakaa ohjeita vasemmalla puolellaan istuvalle, orkesterikanavia säätävälle Parrylle ja oikealla istuvalle, laulajien kanavia säätävälle Brownille. Culshaw pitää myös mikrofonin ja puhelimen avulla yhteyttä äänityssaleissa työskenteleviin muusikoihin ja teknikoihin ja neuvottelee kapellimestari Georg Soltiin äänitettävistä jaksoista. Äänityksen aikana Culshaw toimii ohjaajan $\operatorname{tavoin}^{25}$ antaen komentoja äänenvoimakkuuksista ja äänilähteiden sijoittamisesta stereokuvaan: "Siegfried left, Jimmy, left ... and then Hagen centre". Culshaw pitikin äänilähteiden sijoittamista stereokuvaan klassisen musiikin tuottajan keskeisenä vastuualueena. ${ }^{26}$ Dokumentissa Culshaw'ta, Parrya ja Brownia haastatellaan mikserin ääressä. ${ }^{27}$ Kolmikko vaikuttaa tyytyväiseltä, innostuneelta ja ylpeältä laitteistosta. Culshaw luonnehtii mikseriä ainutlaatuiseksi ja monipuoliseksi (versatile).

Pelkästään orkesterin äänittämiseen käytetään Parryn mukaan 12 mikrofonia ja solistien äänittämiseen useita äänityssalin lavalle riviin asetettuja mikrofoneja. Rakennuksen suuressa salissa (Große Saal) äänitetyn orkesterin kanssa samanaikaisesti kaikuisassa Blauersaalissa äänitetyillä metsästystorvilla on myös omat mikrofoninsa. Filmikatkelmissa äänitallentimina näkyy kaksi (oletettavasti) kaksiraitaista Studer C-37 -nauhuria ja yksi J-37 -neliraitanauhuri. Nauhurikaluston rajallisen raitalukumäärän vuoksi miksaus on pakko tehdä reaaliajassa äänitystilanteessa. Michael Gray kuitenkin selittää, että reaaliaikaista miksausta käytettiin Deccan äänityksissä, koska näin signaalitie saatiin äänitteen tuotantoketjussa mahdollisimman yksinkertaiseksi (äänenlaadun maksimoimiseksi) ja lopputuotetta vastaava miksaus voitiin toistaa heti äänityksen jäl- 
keen artistille tuloksen arviointia varten. ${ }^{28}$ Teknologian rajoitukset käännettiin siis luovalla ratkaisulla eduksi. Kuitenkin kun Sofiensaalin äänityskalusto uusittiin 1970-luvun puolivälissä, WSW-konsoli korvattiin Nevellä, ja studioon hankittiin 16-raitanauhuri. ${ }^{29}$ Näin miksaus jälkituotantovaiheessa tuli ainakin teknisesti mahdolliseksi.

Sound Cityn Neve-konsolin käyttövaiheiden välisestä jaosta voi tutkimusaineiston perusteessa tehdä vaihtoehtoisia tulkintoja. 1. vaiheen voi katsoa kestäneen hankinnasta saakka aina alkuperäisen Sound City -studion toiminnan päättymiseen, mikserin purkamiseen ja siirtoon Dave Grohlin 606 -studioon. Grohlin dokumentissa 1. käyttövaiheen aikaa käsitellään muusikoiden ja henkilökunnan haastattelujen sekä aikalaisvalokuvien kautta, mutta yksityiskohtaisia kuvauksia mikserin käyttötilanteista ei esitetä. Haastatteluotteissa Neve-mikseri ja Sound Cityn yksilön erityinen sointi mainitaan kuitenkin toistuvasti ja laitteesta puhutaan korostuneen ihailevaan, jopa mystifioivaan sävyyn. Dokumentissa haastatellaan myös suunnittelija Rupert Neveä, mutta tässäkin ohjaajan pyrkimyksenä on paremminkin laitteen mystifiointi kuin teknologian avaaminen.

Sound Cityn sosiaalinen ryhmä oli dokumentin valossa huomattavasti moninaisempi kuin tiukasti hierarkkisissa EMI:n ja DECCA:n tuotannoissa. Pienen studion siivooja tai vastaanottoapulainen saattoi edetä nopeasti äänittäjäksi ja tuottajaksi. Toisaalta muusikotkin työskentelivät säännöllisesti tarkkaamon puolella ja olivat näin kosketuksissa miksauskonsolin kanssa.

Dokumentin kertomuksen perusteella Neve-mikseri palveli suunnitellussa käytössään 1980-luvulle, jolloin digitalisaatio alkoi vaikuttaa voimakkaasti äänituotantoon. Sound Cityn laitteistoa ei kuitenkaan uusittu vastaamaan ajan trendejä ja studio rappeutui asiakkaiden ja ylläpidon puutteessa. Murrosvaiheen muodosti Sound Cityssä äänitetty Grohlin oman Nirvana-yhtyeen Nevermind-albumi (1992). Sen kaupallinen menestys ja grunge-musiikin läpimurto toi Sound Cityyn uusia asiakkaita, jotka hakivat erityistä ääni-ilmaisua vanhojen analogialaitteiden käytön avulla.

\section{SUUNNITTELEMATON KÄYTTÖ}

8-raitanauhurin käyttöönotto The Beatles -albumin (1968) äänitysprosessin aikana osoitti neliraitatuotantoon suunnitellun REDD-mikserin ominaisuuksiltaan riittämättömäksi uuteen käyttötilanteeseen. Ongelma ratkaistiin ad hoc -järjestelyllä käyttämällä kahta REDD-konsolia yhden 8-raitanauhurin kanssa. Näin kahdesta konsolista muodostettiin yksi miksausjärjestelmä. Yhden mikserin muodostaman teknologisen kehyksen rajoitukset johtivat näin suunnittelemattomaan käyttöön ja kehyksen laajenemiseen. Samaan aikaan myös konsolin sosiaalinen ryhmä laajeni yhtyeen jäsenten tehdessä äänityksiä myös studio 2:n tarkkaamossa suoraan mikserin ääressä.

The Beatlesin Let it Be-albumin äänitys edusti puhdasta 2 . vaihetta, jossa mikseripari oli jo poistettu EMI:n käytöstä ja lainattiin ulos yhtiön omista tiloista Beatlesin perustaman Apple-yhtiön äänitysstudioon. Siellä miksereitä käytettiin 8-raitaäänityksiin samaan tapaan kuin The Beatles -albumin myöhäisissä äänityksissä.

Sofiensaalin konsolin 2. vaiheen käytöstä ei ole lähdeaineistoa. Gearslutzin keskustelussa on ainoastaan maininta mikserin myynnistä toiseen wieniläiseen studioon. ${ }^{30}$ Voidaan kuitenkin olettaa, että mikseriä ei käytetty enää isoissa oopperatuotannoissa ja suunnittelijoidensa ajattelemalla tavalla.

Elinkaarimallia tiukasti tulkittuna Sound Cityn Neve-konsoli ei kokenut varsinaista suunnittelemattoman käytön vaihetta. Grohlin videodokumentin narratiivin kautta voi kuitenkin tehdä vaihtoehtoisen 
tulkinnan: 1. vaihe kattoi studion kultakauden 1970-luvun alusta 1980-luvulle, jolloin digitaaliteknologian ja uusien äänituotantotapojen voimakas esiinmarssi muutti koko studion vanhentuneeksi. Seurasi taantuma, joka päättyi Nevermind-albumin menestykseen. Tästä alkoi uudenlainen käyttövaihe, jossa mikseriä edelleen käytettiin suunniteltuun käyttötarkoitukseensa suhteessa muihin studion laitteisiin, mutta studio ei enää kokonaisuutena edustanut 1980-luvun huipputeknologiaa vaan retroa, joka pakotti tai kannusti siellä työskennelleet yhtyeet yhteismusisointiin, nopeaan tuotantoprosessiin ja näiden tuottamaan karkeaan ja hiomattomaan lopputulokseen (erotettuna 80-luvun "ylituotetusta" musiikista). Nevemikserikään ei enää edustanut uutta huipputeknologiaa eikä se täyttänyt aiottua tehtäväänsä valtavirta-artistien houkuttelijana. Tässä mielessä kyse oli 2 . vaiheen käytöstä.

\section{UUSIOKÄYTTÖ}

Mikserien uusiokäytöstä on aineistossa eniten tietoa Sound Cityn Nevestä. Sound City -dokumentissa kuvataan pysäytyskuvasekvenssinä studion sulkemista seurannut Neve-konsolin purkaminen ja siirto Grohlin 606 -studioon. Tätä voidaan pitää 2. ja 3. vaiheen välisenä murroksena. Dokumentissa kerrotaan myös, että siirron ja uudelleen kokoamisen yhteydessä konsoli puhdistetiin sinne vuosikymmenten rock-tuotantojen aikana kertyneestä liasta ja "nautintoaineista". Näitä toimenpiteitä voi pitää restaurointina eli 3. vaiheen tunnusmerkkinä. Dokumentissa ei suoranaisesti kerrota Neven teknologian kopioinnista tai mallinnuksesta, mutta digitaalimallinnuksen tuomasta muutoksesta puhutaan muusikoiden haastattelulausunnoissa.

Grohlin dokumentissa kuvataan uusiokäyttövaiheeseen lukeutuvaa Sound City:
From Real to Reel-albumin äänitysprosessia, johon Grohl kutsui joukon Sound Cityssä äänittäneitä tunnettuja muusikoita. Kantavana ideana albumin äänityksissä olivat analogiastudion työtapojen käyttö ja tätä kautta analogiselle pienen budjetin rock-musiikkiäänitykselle tyypillinen yhteismusisointi ja nopea työtahti. Systemaattista kuvausta Neve-konsolin käyttötavoista dokumentti ei kuitenkaan sisällä.

Abbey Roadin studioista poistettiin vuosien mittaan vanhentunutta kalustoa, josta osa päätyi uusiokäyttöön tunnetuille muusikoille. Tiettävästi ainoa säilynyt REDD.51-mikseri on Mark Knopflerin studiossa. Lenny Kravitz puolestaan omistaa REDD.37-mikserin. Abbey Roadilla on edelleen mallisarjan vanhin, REDD.17-konsoli. Näiden uusiokäytöstä on kuitenkin julkaistu varsin niukasti tietoa. Knopflerin ja Kravitzin mikserit kuitenkin esiintyvät joissakin valokuvissa ja Youtubessa julkaistuissa videoleikkeissä. Abbey Roadin REDD.17:ta on myös esitelty studiossa järjestelyillä yleisöluennoilla. Jäljellä olevien laitteiden historiallinen arvo on siis tunnustettu vähintään säilyttämisen muodossa. Knopflerilla olevan, alun perin EMI:n Milanon studiosta löytyneen laitteen restauroinnista on myös esitelmäjulkaisu. ${ }^{31}$ Sofiensaalin mikseriäkin odottaa Gearslutzin keskustelun perusteella museointi tai uusiokäyttö restaurointityön valmistuttua.

\section{KOPIOINTI}

Artikkelin kolmesta konsolista Neven teknologia on selvästi merkittävin laitekopioinnin kohde. Sound Cityn Neve-konsolin keskeisin äänenlaatuun vaikuttanut komponentti oli 1084-vahvistinmoduuli. Komponentti perustuu samoihin vahvistinpiirikortteihin kuin tunnetumpi 1073-malli, joka puolestaan on yksi kopioiduimmista studiolaitteista niin analogisina laitteina kuin di- 
gitaalimallinuksina. Neve 1073 on noussut 2000-luvulla myös laiterakentelijoiden suosioon ja niiden rakentamiseen on saatavilla sekä rakennusohjeita ja komponentteja että valmiita rakennussarjoja. Myös 1084-mallista on saatavilla sekä uusia valmiita laitteita että rakennussarjoja.

Laiterakentelijoista onkin muodostunut yksi mikseriteknologiaa hyödyntävistä ja sen kehitykseen vaikuttavista sosiaalisista ryhmistä. Laiterakenteluyhteisöä pitävät koossa internetin kansainväliset keskusteluryhmät kuten groupdiy.com ja diyaudio.com. Näiden aktiivijäsenet ovat usein yksittäisiä, eri maissa asuvia harrastajia, jotka jakavat kokemuksiaan ja raportoivat rakenteluprojekteistaan keskusteluryhmissä. Groupdiy:n ympärille on 2000-luvulla syntynyt komponenttien välitystoimintaa, valmistusta ja jopa alihankintaketjuja.

Myös REDD-mikserien kanavista on markkinoilla digitaalimallinnuksia, samoin V72- ja REDD.47-vahvistimista. Molemmista vahvistinmalleista on saatavilla myös analogisia laitekopioita. V72 on jo pidempään ollut Neven ohella suosittu kopioinnin kohde. Molemmista on saatavissa runsaasti teknistä dokumentaatiota ja rakenteluun tarkoitettuja erikoiskomponentteja. REDD.47 on rakentelukohteena uudempi. Sofiensaalin miksauskonsolista tai siinä käytetyistä moduuleista ei sen sijaan tiettävästi ole vielä tehty digitaalimallinnusta tai laitekopioita.

Vanhojen laitteiden digitaalimallinnuksessa ei jäljitellä pelkästään laitteen sointia tai toimintoja vaan myös käyttöliittymän ulkoasua. Tällä pyritään luomaan autenttisuuden mielikuvaa. Ilmiö on sinänsä mielenkiintoinen ja oman tutkimuksensa arvoinen. Digitaalimallinnusteknologian käyttäjä voi kuvitella pystyvänsä työskentelemään samoilla välineillä kuin suurten, kuuluisien äänitysstudioiden äänittäjät. Ilmiöön voi liittää yhtä lailla kuuluisien artistien, äänittäjien ja itse teknologian fanitusta kuin nostalgi$\mathrm{aa}^{32}$ - toisaalta myös uuden teknologian tai työtapojen vastustusta. ${ }^{33}$ Vanhojen laitteiden jäljittelyyn liittyy myös purismi eli täydellisen kopion ihannointi ja tästä kumpuava "epätäydellisten" laitekopioiden tai mallinnusten äänekäs kritisointi keskustelufoorumeilla ja sosiaalisessa mediassa.

Myös laitevalmistajat näyttävät hyödyntävän rakentelijafoorumeiden avoimesti jakamaa tietoa laitteiden yksityiskohdista ja tuovat tälle perustuvia laitekopioita markkinoille. Valmistajat myös perustelevat laitteiden autenttisuutta elektroniikkakomponenttivalinnoilla, mikä osoittaa, että potentiaaliset ostajat tuntevat laitteiden tekniset yksityiskohdat varsin tarkasti.

Jo ennen laitekopioiden tai mallinnuksien yleistymistä mikserien teknologiaa kierrätettiin myös purkamalla käytöstä poistettujen mikserien moduuleja ja rakentamalla näistä erillislaitteita. Tässäkin Neven moduulit olivat suosituimpien kierrätystavaroiden joukossa. Dave Grohlin ansioista Sound Cityn Neve-konsoli onnistui kuitenkin välttämään tämän kohtalon.

\section{VANHAN TEKNOLOGIAN RAJOITUKSET LUOVAN TOIMINNAN MAHDOLLISTAJINA}

Ryan ja Kehew käsittelevät läpi kirjansa EMI:n perinteistä jäykkää ja hierarkkista roolijakoa ja työtapaa, joka muuttui vuosikymmenen loppua kohti väljemmäksi ja vapaammaksi. Talon säännöt rajoittivat teknologian soveltamista ja olivat siten myös osa studion teknologista kehystä itse laitteiden ohella. Luovan toiminnan mahdollistajia olivat puolestaan teknikoille maksetut keksintöpalkkiot, jotka synnyttivät sekä vanhojen laitteiden uusia, suunnittelemattomia käyttötapoja, että kokonaan uusia pienlaitteita. Näitä innovaatioita edustivat muun muassa automaattinen tuplaus (Automatic Double-Tracking), jolla lauluääni saatiin kuulostamaan kahteen kertaan äänitetyltä 
käyttämällä nauhureita luovalla tavalla sekä sähköbasson äänittäminen DI-boxin avulla ilman bassovahvistinta ja mikrofonia.

Teknologisen kehyksen rajoitukset haastoivat käyttäjiä kekseliäisyyteen, joka joskus johti myös ennakoimattomien, uusien sointien löytämiseen. Näin tapahtui esimerkiksi kääntämällä nauha takaperin tai soittamalla vaikea osuus puolella nopeudella ja nostamalla nauhanopeus esitystempon mukaiseksi. Tämä puolestaan muutti äänitetyn soittimen sointia jopa tunnistamattomaksi. Neliraitatallennuksen rajoitukset pakottivat usein äänittämään useita instrumenttiosuuksia samalle raidalle, mikä puolestaan pakotti tarkkaan yhteissoittoon.

REDD-mikserin korvaaminen uudenaikaisella 8-raitatallennukseen suunnitellulla TG.12345-mikserillä poisti suuren osan vanhan mikserin rajoituksista. Äänittäjä Geoff Emerickin mukaan ${ }^{34}$ REDD-mikserissä oli silti äänellisiä ja tottumukseen liittyviä etuja, eikä uuden mikserin käyttöönotto ollut yksinomaan positiivinen kokemus.

Sound City -dokumentin jälkipuolen haastatteluissa keskeisenä teemana on analogisen äänitysteknologian vaikutus musiikin tekemiseen. Haastatteluissa vanhan teknologian rajoitukset esitetään luovan työn mahdollistajana. Lausunnoissa muistellaan haikaillen vanhan studion yhteisöllisyyttä ja sitä, kuinka teknologian rajoitukset pakottivat muusikot suoraviivaiseen työtapaan, hyväksymään virheitä, musisoimaan yhdessä ja keksimään luovia ratkaisuja. Soittajien täytyi osata "oikeasti" soittaa. Sitä vastoin uusi digitaalinen teknologia on "- mahdollistanut ihmisten, joilla ei ole asiaa musiikkibisnekseen, tulla tähdiksi." 35 Vanha analoginen teknologia vaikuttaa dokumentin valossa sekä musiikin sointiin että musisointiprosessiin. Uutta digitaaliteknologiaa ei silti esitetä yksinomaan negatiivisessa valossa, vaan myös sen luovaa työtä mahdollistavaa puolta tuodaan esiin.
Grohl kertoo aikoneensa alun perin tehdä dokumenttinsa pelkästään Neve-konsolista. Dokumentissa tuottaja-äänittäjä Jim Scott kertoo ja havainnollistaa, miten Nevekonsoli kuulostaa hyvältä, myös signaalin yliohjautuessa. ${ }^{36}$ Sound Cityn Neveä luonnehditaan useissa haastatteluotteissa soinniltaan ainutlaatuiseksi yksilöksi. 2010-luvulla tehdyistä haastatteluista ei kuitenkaan voi suoraan päätellä, suhtautuivatko käyttäjät 1970-luvulla yhtä ihailevasti konsoliin ja kuinka tarkoituksellisesti Grohl itse on pyrkinyt rakentamaan Nevelle erityisen laitteen asemaa. REDD-konsolin osalta Ryan ja Kehew ovat ajan kuvauksessa avoimempia: The Beatlesin äänittäjät eivät aina pitäneet työtään erityisen houkuttelevana, koska äänityssessioiden aikataulut kävivät ajan mittaan epäsäännöllisiksi ja arvaamattomiksi. ${ }^{37}$ Suhtautumisesta itse teknologiaan ei tämäkään silti kerro. Molemmissa studioissa käyttäjät olivat joka tapauksessa sidoksissa konsolin muodostamaan teknologiseen kehykseen. Culshaw'n tuotantoryhmän tyytyväisyys omaan konsoliinsa tulee sen sijaan filmiaineistossa selvästi esiin.

\section{KÄYTTÄJIEN VAIKUTUS MIKSEREIDEN KÄYTTÖLIITTYMÄASETTELUUN}

Mikseriteknologian kehittyminen näkyy erityisen selvästi konsolien käyttöliittymissä. Käyttäjien vaikutuksella on ollut tässä merkittävä rooli. REDD-konsolien rakenne ja säätimien asettelu määräytyivät pitkälti elektroniikan ehdoilla: mikseri vaati toimiakseen kymmeniä vahvistinmoduuleita, jotka painonsa, kokonsa ja lämmön tuottonsa vuoksi oli käytännöllistä sijoittaa jalustoina toimiviin sivuosiin molemmin puolin pöytätason alle. Vahvistinkoteloiden symmetrisen asettelun vuoksi myös käyttöliittymä oli käytännöllistä järjestää symmetriseksi, jotta vahvistimien ja säätimien väliset johtimet saatiin mahdollisimman lyhyiksi. Järjestely 
varmasti myös helpotti mikserin purkamista ja kokoamista. Tämä jo GLC-mikseristä peräisin oleva rakenne säilyi konsolisarjan loppuun asti. REDD-miksereitä voi näin ollen pitää pitkälti suunnittelijansa tuotteena ja käyttäjien vaikutus näkyi selvemmin 8-raitatuotantoon suunnitellussa TG.12345konsolissa.

Deccan mikserin toteutuksessa näkyi käyttäjien vaikutus puolestaan selvästi, mikä pohjautui Deccan tuotantotiimin työskentelykokemuksiin aiemmalla miksauskalustolla. Mikserin symmetrinen muotoilu johtuikin enemmän käyttäjien työtavoista kuin elektroniikan asettamista rajoituksista. Mikseri rakennettiin kiinteäksi osaksi tilavaa tarkkaamohuonetta eikä koosta tarvinnut tinkiä. Lisäksi transistoritekniikkaan perustuneet mikrofonivahvistimet olivat REDD:in vahvistinmoduuleita pienempiä, mikä helpotti niiden sijoittelua. Toisaalta tiettyä työtapaa varten rakennettu mikseri oli omalla tavallaan rajoittunut: yhden äänittäjän oli käytännössä mahdotonta käyttää koko mikserin kanavamäärää suunnitellulla tavalla, koska kanavapuoliskot olivat etäällä toisistaan ja niitä erotti tuottajan työpiste.

Neven 80-sarjan miksereissä moduulien asettelu voitiin järjestää osin käyttäjien toiveiden mukaisesti. Pääosin niissä käytettiin kuitenkin epäsymmetristä asettelua, jossa sisääntulokanavat sijaitsivat vasemmalla ja ryhmiin, signaaliulostuloihin sekä nauhakuunteluun liittyvät säätimet oikealla. Tällainen epäsymmetrinen asettelu yleistyi sittemmin myös projektistudiolle ja liveäänentoistoon suunniteltujen integroitujen mikserien käyttöliittymissä. Mikserin käyttöliittymän vakiintuminen oli osin sekin käyttäjien vaikutusta, koska se helpotti uuden mikserin käytön opettelua siirryttäessä studiosta toiseen. Myös yksittäisten moduulien käyttöliittymä ja toiminnallisuus alkoi olla vakiintunutta eri laitevalmistajien kesken.
Myös symmetrisellä asettelulla on edelleen kannattajansa. Abbey Roadin miksereissä käytettiin symmetristä asettelua REDDkonsolien jälkeenkin sekä REDD.51:n korvanneessa TG.12345-mikserissä että 2000-luvun konsoleissa. ${ }^{38}$ Yhtenä syynä tähän puolestaan lienevät EMI:n omat talon käytännöt ja tottumukset sekä laitesuunnittelussa että käytössä. EMI:n äänittäjät olivat ainakin vielä 1960-luvulla yhtiön vakituisia ja talon sisällä kouluttautuneita työntekijöitä ja hankkineet kokemuksensa nimenomaan yhtiön omilla laitteilla, siis juuri symmetrisesti asetelluilla miksereillä. Symmetristä asettelua käytetään erityisesti suurissa konsoleissa, joissa etäisyydet laitimmaisten kanavien ja ryhmien välillä kasvavat suuriksi.

Yhteistä asetteluille kuitenkin on, että kaikki mikserin säätimet ovat yhden äänittäjän ulottuvilla ilman tuottajalle varattua työtilaa. Tähän ovat olleet osasyinä äänittäjän ja tuottajan välisen tehtäväjaon hämärtyminen ja tuottajan roolin muuttuminen puhtaasti taiteellisesta toimijasta myös laitteiston käyttäjäksi.

\section{JOHTOPÄÄTÖKSET}

Kärjistetysti kuvailtuna analoginen miksauskonsoli on kokenut varsin stereotyyppisen lajityyppievoluution pienistä esiasteista suuriin kolosseihin ja lajin osittaiseen häviämiseen. Miksauskonsolien kokoa ja toiminnallisuutta tarkasteltaessa lajityypin huippukausi oli 1970- ja 1980-luvulla, jolloin puolijohdeteknologia ja komponenttien integraatio mahdollistivat kanavalukumäärältään yhä suurempien konsolien rakentamisen. 1990-luvulla digitaaliteknologia ja tietokonepohjainen työskentely alkoivat korvata analogista tallentamista ja miksaustehtäviä alettiin myös tehdä tietokoneilla ilman analogista miksausvaihetta. Mikseri muuttui näin varsin nopeasti välttämättömästä moniraitaäänittämisen työvälineestä 
jäänteeksi, jota käytettiin ehdottoman tarpeen sijaan toissijaisista syistä, esimerkiksi tottumuksesta, tietynlaisen soinnin saavuttamiseksi tai muunlaisesta mieltymyksestä. Isoissa kaupallisissa studioissa on silti edelleen miksauskonsoleita, jotta ne ovat tunnistettavissa äänitysstudioksi ja markkinoitavissa sellaisina riippumatta siitä, käytetäänkö laiteita äänitteiden miksauksessa. Myös Abbey Roadin 2 studiossa on yhä suuri miksauskonsoli, analoginen AMS Neve 88RS (ks. kuva 2) - osittain symmetrisellä käyttöliittymäasettelulla.

Miksauskonsolin teknologia vaikuttaa yhä äänituotantoon työprosessien, käyttöliittymäsuunnittelun ja soinnin alueilla. Miksaus on edelleen keskeinen äänituotannon työvaihe ja se suoritetaan DAW-ohjelmissa yleensä analogista mikseriä muistuttavalla käyttöliittymällä. Niissäkin isommissa äänitysstudioissa, joissa ei ole miksauskonsolia, on yleensä mikserin käyttöliittymää muistuttava DAW-ohjelman ohjainlaite. Tämäkin on osoitus miksauskonsolin käyttöliittymän vakiintuneesta asemasta.

2000-luvulla kiinnostus analogiseen studioteknologiaan on kuitenkin jopa laajempaa kuin sen valtakautena 1930-1980 -luvuilla. Syinä tähän voidaan pitää tietokoneiden mahdollistamaa äänitysharrastuksen suosion kasvua, ohjelmistoliitännäisten valikoimaa ja internetin kautta leviävää tietoa laitteista. Sekä ammatti- että harrastajaäänittäjät hakevat esikuvia kokeneempien ja kuuluisampien äänittäjien piiristä. Esikuvien laitevalinnat vaikuttavat siten myös vanhojen studiolaitteiden yleistymiseen ja kanonisoitumiseen. Mikseriteknologian parissa työskentelevä sosiaalinen ryhmä tai ryhmien joukko synnyttää väistämättä myös uusia teknologian käyttötapoja.

Miksauskonsolin kehitys on sekä artikkelin aineiston että laajemman studioteknologian historiatutkimuksen valossa ollut huomattavasti suoraviivaisempaa ja "helpompaa" kuin Bijkerin ${ }^{39}$ käsittelemien teknologioiden. Esimerkiksi polkupyörän kehitykseen liittyi erityisesti alkuvaiheessa useita vaihtoehtoisia rakenneratkaisuja ennen teknologian vakiintumista nykyisen kaltaiseen kaksipyöräiseen artefaktiin. Pinch ja Trocco puolestaan nostavat esiin jännitesäätöisten syntetisaattorien kehittäjien Bob Moogin ja Donald Buchlan keskenään erilaiset laitesuunnittelun lähtökohdat ja suhtautumisen käyttäjiin. ${ }^{40}$ Varhaisen syntetisaattoriteknologian "tulkinnallinen joustavuus" (interpretative flexibility) loi heidän laitteilleen myös erilaiset teknologiset kehykset. Mikserit olivat sitä vastoin toiminnoiltaan hyvin samanlaisia ja noudattivat aikansa elektroniikan yleistä kehitystä. Näkyvimpiä poikkeamia ja merkkejä käyttäjien vaikutuksesta olivat yllä mainitut käyttöliittymäasettelut. Näissäkään mikseri ei ole löytänyt yhtä ainoaa vakiintunutta muotoa esimerkiksi epäsymmetrisen tai symmetrisen asettelun välillä.

Kuva 2. Abbey Roadin Studio 2:n Neve 88RS -konsoli elokuussa 2018. 
Artikkelissa esitellyllä nelivaiheisella elinkaarimallilla voidaan tarkastella sekä yksittäisiä artefakteja että kokonaista teknologiaa yhtenäisen, joskin väljän, käsitteistön ja kriteeristön kautta. Mallia voikin soveltaa mikseriteknologian ulkopuolelle. Esimerkiksi 1960-luvulla markkinoille tulleiden analogisten modulaaristen syntetisaattorien kehityksestä voi löytää samanlaisia piirteitä. ${ }^{41}$ Nämä soittimet toimivat myös hyvänä vertailukohtana ja avaavat mielenkiintoisen tarkastelukulman analogisten miksauskonsolien tulevaisuuden arviointiin: monet 1960- ja 1970-luvun syntetisaattoriyksilöt ovat läpikäyneet samoja käyttövaiheita uusiokäyttöineen ${ }^{42}$ ja teknologian kopiointeineen kuin tämän tekstin miksauskonsolit. Välillä jo valmistuksesta lähes hävinnyt soitintyyppi on 2000-luvulla noussut tarjonnaltaan yhdeksi soitinteollisuuden nopeimmin kasvavista tuoteryhmistä. Modulaarisyntetisaattorit ovat jo yleisempiä muusikoiden keskuudessa kuin 1960- ja 1970-luvulla ennen digitaaliteknologian yleistymistä. Kyse onkin saman teknologian uudesta 1. käyttövaiheesta. Näin ollen elinkaarimallia ei pidä nähdä lineaarisena yksisuuntaisena kehityksenä vaan joissakin tapauksissa - ellei aina - syklisenä.

Analogisen miksauskonsolin tulevaisuutta on kuitenkin vaikea arvioida, koska käyttäjien kykyä soveltaa teknologiaa ei voi ennustaa. Tämä on myös SCOT-tutkimuksen ydinlähtökohta ja tästä Oudshoorn ja Pinch esittävät hyvin dramaattisiakin esimerkkejä. ${ }^{43}$ Modulaaristen syntetisaattorien kehityksen valossa voidaan silti ainakin arvailla, kokeeko analoginen miksauskonsolikin vielä samanlaisen teknologisen renessanssin.

FT Kai Lassfolk toimii musiikkitieteen professorina Helsingin yliopistossa keskeisinä erityisaloinaan laskennallinen musiikintutkimus, musiikkiteknologian tutkimus ja arkeoakustiikka.

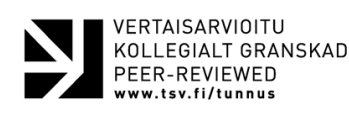

${ }^{1}$ Ks. Bijker 1995; Pinch \& Trocco 2004; Oudshoorn \& Pinch 2005.

${ }^{2}$ Product Life Cycle (PLC), ks. esim. Rink \& Swan 1979.

${ }^{3}$ Ryan \& Kehew 2006.

${ }^{4}$ Burton 2012[1965].

${ }^{5}$ Grohl 2013.

${ }^{6}$ Esim. Théberge 2004; Watson 2015.

${ }^{7}$ Lassfolk 2015.

${ }^{8}$ Gearslutz 2018.

${ }^{9}$ Vrt. Bijker 1995, 190-197.

${ }^{10}$ Esim. Baxandall 1994, 284.

${ }^{11}$ Esim. Schmidt Horning 2013, 108-109.

12 Schmidt Horning 2013, 171.

${ }^{13}$ Ks. Massey 2015.

${ }^{14}$ Ks. esim. Cogan \& Clark 2003; Schmidt Horning 2013.

${ }^{15}$ Ryan \& Kehew 2006, 6-7.

${ }^{16}$ Ryan \& Kehew 2006, 72-75.

${ }^{17}$ Ryan \& Kehew 2006, 68-70.

${ }^{18}$ Culshaw 2012[1967].

${ }^{19}$ Culshaw 2012[1967], 50-52.

${ }^{20}$ Ks. esim. Gearslutz 2018; Borwick 1970.

${ }^{21}$ Grohl 2013, 00:11:50.

${ }^{22}$ CPI Inflation Calculator 2018.

${ }^{23}$ Ryan \& Kehew 2006, 104.

${ }^{24}$ Borwick 1970; Gray 2013, 133.

${ }^{25}$ Burton 2012[1965], 00:08:53.

${ }^{26}$ Culshaw 1976, 256

${ }^{27}$ Burton 2012[1965], 00:27:11.

${ }^{28}$ Gray 2013, 126-127.

${ }^{29}$ Emt.

${ }^{30}$ Gearslutz 2018.

${ }^{31}$ AES 2018.

${ }^{32}$ Ks. esim. Pinch \& Reinecke 2009; Lindsay 2005 , 46.

${ }^{33}$ Vrt. Kline 2005.

${ }^{34}$ Ryan \& Kehew 2006, 113.

${ }^{35}$ Grohl 2013, 01:04:06.

${ }^{36}$ Grohl 2013, 00:14:00-00:14:20.

${ }^{37}$ Ryan \& Kehew 2006, 50, 462.

${ }^{38}$ Ryan \& Kehew 2006, 117.

${ }^{39}$ Bijker 1995.

${ }^{40}$ Pinch \& Trocco 2004, 310-311. 
${ }^{41}$ Ks. esim. Pinch \& Trocco 2004.

${ }^{42}$ Pinch \& Trocco 2004, 305.

${ }^{43}$ Oudshoorn \& Pinch 2005.

\section{TUTKIMUSAINEISTO}

\section{Tallenteet}

BURTON, Humphrey (ohj.). The Golden Ring. Dokumenttielokuva. BBC, London 2012[1965].

GROHL, David (ohj.). Sound City. Dokumenttielokuva, DVD-levy. Roswell Films / Sony Music, LC o0316. 8876545895 9. 2013.

\section{Verkkoaineisto}

AES. Restoring the EMI REDD51 mixing console. http://www.aes-uk.org/forthcoming-meetings/ restoring-the-emi-redd51-mixing-console/. Tarkistettu 10.6.2018.

CPI INFLATION CALCULATOR. Bureau of Labor Statistics. https://www.bls.gov/data/inflation_calculator.htm. Tarkistettu 7.11.2018.

GEARSLUTZ. Decca WSW Console Restoration. https://www.gearslutz.com/board/highend/1003805-decca-wsw-console-restauration. html. Tarkistettu 10.6.2018.

\section{Painettu aineisto}

BORWICK, John. Decca's Vienna Venue. DB Magazine, January 1970, 26-27.

GRAY, Michael. The Story of Decca/London FFSS. Decca Sound. The Analog Years. Levyvihko. Decca 478 5437. Decca, London 2013.

\section{LÄHDEKIRJALLISUUS}

BAXANDALL, Peter. Microphone Amplifiers and Transformers. Teoksessa Microphone Engineering Handbook. Toim. Michael Gayford. Focal Press, Oxford 1994.

BIJKER, Wiebe E. Of Bicycles, Bakelites, and Bulbs. Toward a Theory of Sociotechnical Change. The MIT Press, Cambridge (Mass.) 1995.

COGAN, Jim \& CLARK, William. Temples of Sound: inside the great recording studios. Chronicle Books, San Francisco 2003.

CULSHAW, John. The Rôle of the Producer. Teoksessa Sound Recording Practice. Toim. John Borwick. Oxford University Press, London 1976.

CULSHAW, John. The Ring Resounding. Kirjan uudelleenjulkaisu albumissa Wagner: Der Ring Des Nibelungen, Solti. Decca Deluxe Limited Edition. Decca 02894783702 2. 2012[1967].
KLINE, Ronald. Resisting Consumer Technology in Rural America: The Telephone and Electrification. Teoksessa How Users Matter. The Co-construction of Users and Technology. Toim. Nelly Oudshoorn ja Trevor Pinch. The MIT Press, Cambridge (Mass.) 2005.

LASSFOLK, Kai. Sound City: Musiikkidokumentti studiotyön murrosten kuvaajana. Musiikin suunta 3/2015, 48-53.

LINDSAY, Christina. From the Shadows: Users as Designers, Producers, Marketers, Distributors, and Technical Support. Teoksessa How Users Matter. The Co-construction of Users and Technology. Toim. Nelly Oudshoorn ja Trevor Pinch. The MIT Press, Cambridge (Mass.) 2005.

MASSEY, Howard. The Great British Recording Studios. Hal Leonard, Millwaykee (WI) 2015.

OUDSHOORN, Nelly \& PINCH, Trevor. Introduction: How Users and Non-Users Matter. Teoksessa How Users Matter. The Co-construction of Users and Technology. First paperback edition. Toim. Nelly Oudshoorn ja Trevor Pinch. The MIT Press, Cambridge (Mass.) 2005.

PINCH, Trevor \& REINECKE, David. Technostalgia: How Old Gear Lives on in New Music. Teoksessa Sound Souvenirs. Audio Technologies, Memory and Cultural Practices. Toim. Karin Bijsterveld ja José van Dijck. Amsterdam University Press, Amsterdam 2009.

PINCH, Trevor \& TROCCO, Frank. Analog Days. The Invention and Impact of the Moog Synthesizer. Harward University Press, Cambridge (Mass.) 2004.

RINK, David R. \& SWAN, John E. Product Life Cycle Research: A Literature Review. Journal of Business Research. Vol. 7, Issue 3 (September 1979) 219-242.

RYAN, Kevin \& KEHEW, Brian. Recording The Beatles. Curvebender Publishing, Houston (Texas) 2006.

SCHMIDT HORNING, Susan. Chasing Sound. Technology, Culture \& the Art of Studio Recording from Edison to the LP. The Johns Hopkins University Press, Baltimore 2013.

THÉBERGE, Paul. The Network Studio: Historical and Technological Paths to a New Ideal in Music Making. Social Studies of Science 34/5 (October 2004) 759-781.

WATSON, Allan. Cultural production in and beyond the recording studio. Routledge, New York 2015. 